\title{
Studies of the action of vitamin $D$ in the rat
}

\author{
By ELISABETH M. CHEESMAN AND ALICE M. COPPING \\ Departments of Physiology and Nutrition, Queen Elizabeth College, \\ University of London, Campden Hill Road, London, $W 8$ \\ (Received 7 October 1968-Accepted 30 December 1968)
}

\begin{abstract}
I. Rats were given a rachitogenic diet for 28 days; some were dosed with vitamin D 2 or 3 days before they were killed and some received vitamin $D$ throughout the experiment.

2. Parathyroid leucine aminopeptidase was measured histochemically as an index of parathyroid activity and silver impregnation as a criterion of bone calcification.

3. Calcium and phosphorus were estimated in bone ash and in serum. In rats killed 2 days after a single dose of vitamin $D$, increases were found in the $C a$ and $P$ content of serum and bones and in epiphyseal $\mathrm{Ca}$ deposition. Parathyroid activity was decreased. In rats killed 3 days after a dose of vitamin $D$ there was a marked increase in serum $C a$ and $P$ but a less clear change in bone $\mathrm{Ca}$ and $\mathrm{P}$ although epiphyseal calcification was evident. The parathyroid activity was less than in rats dosed throughout the experiment.
\end{abstract}

In previous studies of the effect of vitamin $D$ on enzyme activities in the rat (Cheesman, Copping \& Prebble, I964, I966), changes were observed after I-7 weeks' deprivation and after $\mathrm{I}$ week of recovery. The leucine aminopeptidase activity of the parathyroids appeared to be the most sensitive index of the vitamin $\mathrm{D}$ status of the animal. In the present study an attempt was made to ascertain the time required for a measurable response to vitamin $\mathrm{D}$ in parathyroids, serum and bones of deprived rats. For this purpose rats given a single curative dose of vitamin $\mathrm{D}$ were compared with deficient and normal rats.

\section{EXPERIMENTAL}

\section{Animals and procedure}

Litter-mate pairs $\left(\mathrm{C}_{45}\right)$ or trios $\left(\mathrm{C}_{4} 6\right)$ of male rats of the Lister Institute black and white stock maintained at Queen Elizabeth College were placed on Steenbock's rachitogenic diet 2965 (Steenbock \& Black, 1925) at 28 days of age. The diet was given for 28 days with addition of vitamin $A$ and with or without vitamin D. Some of the deprived rats were given a single dose of $\mathrm{s}$ o i.u. vitamin $\mathrm{D}$. These are referred to as 'recovery' animals.

In series $\mathrm{C}_{45}$ both rats received the unsupplemented rachitogenic diet for 28 days, one having the single dose of vitamin $\mathrm{D}_{4} 8 \mathrm{~h}$ before killing. In series $\mathrm{C}_{4} 6$ two rats had no supplement, one of this pair having the single dose of vitamin $\mathrm{D}_{72} \mathrm{~h}$ before killing; the third rat received vitamin $\mathrm{D}$ throughout the 28 days.

\section{Preparation of tissues}

For determination of serum $\mathrm{Ca}$ and $\mathrm{P}$, blood was collected from the tail vein under sodium barbital anaesthesia, allowed to clot, centrifuged and the serum decanted and stored at $-10^{\circ}$. Wilk $\&$ King ( 1963 ) showed that storage under these conditions did not affect $\mathrm{Ca}$ determinations. 
The animals were then killed and tissues for histochemical examination and analysis of bone ash were prepared as described previously (Cheesman et al. 1964, 1966).

\section{Histochemical examination and scoring}

Leucine aminopeptidase was localized in the parathyroids by the method of Nachlas, Crawford \& Seligman (Pearse, 1960, p. 913). Pairs of sections were examined with a Britex projection comparator (Pyser-Britex Ltd, 329 High Holborn, London, $\mathrm{WC}$ I) and scored as below:

$$
\begin{aligned}
& \pm 3 \text { very great difference in activity, } \\
& \pm 2 \text { great difference in activity, } \\
& \pm \text { I difference in activity, } \\
& \text { o no difference in activity. }
\end{aligned}
$$

The convention was adopted that when a section from a normal animal had the greater activity the score was + . When a section from a deficient animal had the greater activity the score was - . When normal and recovery animals were compared, greater activity in the recovery animal was scored -. When deficient and recovery animals were compared, greater activity in the recovery animal was scored + .

Wrists were stored at $-10^{\circ}$ and then impregnated with silver by the method of Lillie ( 1928$)$ to demonstrate the distribution of $\mathrm{Ca}$ around the epiphyseal plate. The wrists were then decalcified in EDTA (Balogh, 1962) and sections cut at $15 \mu \mathrm{m}$ in a cryostat.

\section{Ca and $P$ determination}

The right femur, tibia and fibula were ashed by the procedure of Hume, Pickersgill \& Gaffikin (1932). The ash was dissolved in $10 \mathrm{ml} \mathrm{N}-\mathrm{HCl}$, placed in a boiling water bath for $10 \mathrm{~min}$ and then diluted to $100 \mathrm{ml}$. Ca was determined in ash solutions and in serum by titration with EDTA with murexide as a complexometric indicator (Wilkinson, 1960, p. 84).

$\mathrm{P}$ was determined in ash solutions and serum by Wilkinson's modification of the method of Fiske \& Subba Row (Wilkinson, 1960, p. 89).

\section{RESULTS}

\section{Parathyroid}

The means of the histochemical scores for the parathyroids are given in Table I.

The significances of the scores were estimated by the Wilcoxon matched-pairs signed-ranks test (Siegel, 1956, p. 75). The leucine aminopeptidase activity of the parathyroids in series $\mathrm{C}_{45}$ had decreased within 2 days of a dose of vitamin $\mathrm{D}$ after 26 days of previous depletion $(P=0.05)$. In series $\mathrm{C}_{4} 6$ a dose of vitamin $\mathrm{D}$ given after 25 days of depletion decreased the activity of the parathyroids of the recovery rats below that of the normal rats $(P=0.02)$.

\section{$C a$ and $P$ in serum and bone ash}

The results set out in Table 2 showed a significant increase in $\mathrm{Ca}$ and $\mathrm{P}$ content of serum and bone ash within 2 days of dosing with vitamin $\mathrm{D}(P<0.0 \mathrm{I})$ in series $\mathrm{C}_{45}$. 
In series $\mathrm{C}_{4} 6$ the rise in serum $\mathrm{Ca}$ and $\mathrm{P}$ in the recovery rats was highly significant $(P<0.001)$ although the serum $P$ was still below the normal level $(P<0.01)$, while the serum $\mathrm{Ca}$ was the same as in the normal animals. There was in these animals no significant rise in the bone $\mathrm{Ca}$ or $\mathrm{P}$ during recovery.

The ratio of $\mathrm{Ca}$ to $\mathrm{P}$ in bone ash was in all instances very close to $2: \mathrm{I}$, which agrees with results reported for leg bones of rats having a similar diet (Kramer \& Shear, 1928). This was found for individual animals as well as for mean values as set out in Table 2.

Table I. Mean values for the differences in histochemical scores of the parathyroids of rats given a rachitogenic diet with or without vitamin $D$ and results for the Wilcoxon matched-pairs signed-ranks test

$\begin{array}{ccccccc}\begin{array}{c}\text { Series } \\ \text { no. }\end{array} & \begin{array}{c}\text { Experimental } \\ \text { period } \\ \text { (days) }\end{array} & \begin{array}{c}\text { No. of } \\ \text { pairs } \\ \text { of rats }\end{array} & \text { Comparison } & \begin{array}{c}\text { No. of } \\ \text { pairs } \\ \text { where } \\ \mathrm{d}^{*}=0\end{array} & \mathrm{~T} \uparrow & \begin{array}{c}\text { Leucine } \\ \text { amino- } \\ \text { peptidase }\end{array} \\ \mathrm{C}_{45} & 28 & 8 & \text { R } v . \mathrm{D} & 2 & 0.0 & -0.8 \\ \mathrm{C}_{46} & 28 & 8 & \text { N } v . \mathrm{D} & 0 & 0.0 & -\mathrm{I} \cdot 7 \\ \mathrm{C}_{46} & 28 & 9 & \text { N } v . \mathrm{R} & 2 & 0.0 & +0.9 \\ \mathrm{C}_{46} & 28 & 8 & \text { R v. D } & 0 & 0.0 & -2 \cdot 4\end{array}$

$\mathrm{N}$, normal animals, vitamin $\mathrm{D}$ throughout the experimental period.

$\mathrm{D}$, deficient animals, no vitamin $\mathrm{D}$ during the experimental period.

$R$, recovery animals, vitamin D $48 \mathrm{~h}\left(\mathrm{C}_{45}\right)$ or $72 \mathrm{~h}\left(\mathrm{C}_{4} 6\right)$ before the end of the experimental period.

* $d$ is the difference between pairs of sections.

$+T$ is the smaller sum of the like-signed ranks.

Table 2. Mean values with their within-litters standard errors for calcium and phosphorus content of serum and bone ash of rats given a rachitogenic diet with or without vitamin $D$

\begin{tabular}{|c|c|c|c|c|c|c|c|}
\hline \multirow{2}{*}{$\begin{array}{c}\text { Series } \\
\text { no. }\end{array}$} & \multirow{2}{*}{$\begin{array}{c}\text { Experi- } \\
\text { mental } \\
\text { period } \\
\text { (days) }\end{array}$} & \multirow{2}{*}{$\begin{array}{l}\text { Dosing } \\
\text { period } \\
\text { (days) }\end{array}$} & \multirow{2}{*}{$\begin{array}{l}\text { No. of } \\
\text { rats }\end{array}$} & $\begin{array}{c}\text { Serum } \\
\mathrm{Ca}\end{array}$ & $\begin{array}{l}\text { Serum } \\
\quad P\end{array}$ & $\begin{array}{l}\text { Bone ash } \\
\quad \mathrm{Ca}\end{array}$ & $\begin{array}{c}\text { Bone ash } \\
\mathrm{P}\end{array}$ \\
\hline & & & & \multicolumn{2}{|c|}{$(\mathrm{mg} / 100 \mathrm{ml})$} & \multicolumn{2}{|c|}{ (mg in total ash) } \\
\hline $\begin{array}{l}\mathrm{C}_{45} \\
\mathrm{C}_{45}\end{array}$ & $\begin{array}{l}28 \\
28\end{array}$ & $\begin{array}{l}\circ \\
2^{*}\end{array}$ & $\begin{array}{l}8 \\
8\end{array}$ & $\left.\begin{array}{l}11 \cdot 5 \\
12 \cdot 3\end{array}\right\} \pm 0.12$ & $\left.\begin{array}{l}4 \cdot 4 \\
6.3\end{array}\right\} \pm 0.27$ & $\left.\begin{array}{l}45 \cdot 7 \\
49 \cdot 4\end{array}\right\} \pm \mathrm{I} \cdot \mathrm{OI}$ & $\left.\begin{array}{l}21 \cdot 8 \\
23.0\end{array}\right\} \pm 0.22$ \\
\hline $\begin{array}{l}\mathrm{C}_{46} 6 \\
\mathrm{C}_{46} \\
\mathrm{C}_{46} 6\end{array}$ & $\begin{array}{l}28 \\
28 \\
28\end{array}$ & $\begin{array}{c}0 \\
28 * \\
3 *\end{array}$ & $\begin{array}{l}\text { II } \\
\text { II } \\
\text { II }\end{array}$ & $\left.\begin{array}{l}10 \cdot 0 \\
12 \cdot 1 \\
12 \cdot 1\end{array}\right\} \pm 0.16$ & $\left.\begin{array}{l}2 \cdot 7 \\
4 \cdot 7 \\
4 \cdot 1\end{array}\right\} \pm 0 \cdot 16$ & $\left.\begin{array}{l}38 \cdot 6 \\
54 \cdot 3 \\
38 \cdot 9\end{array}\right\} \pm 1 \cdot 20$ & $\left.\begin{array}{l}17.9 \\
26.0 \\
18.4\end{array}\right\} \pm 0.53$ \\
\hline
\end{tabular}

* Weekly dose or single dose ro i.u. vitamin D.

\section{Calcification of radius and ulna}

Characteristic photomicrographs are shown in Pl. I.

In series $\mathrm{C}_{45}$ there were no normal rats for comparison, and the usual signs of vitamin D deficiency, wide and irregular epiphyseal plate, were not very marked. However, the extension of areas of calcification into the epiphyseal cartilage made it possible to differentiate between dosed and undosed rats.

In series $\mathrm{C}_{4} 6$ the contrast between deficient and normal animals was very marked. The recovery animals showed a strong surge of calcification into the epiphyseal plate. 
They could be clearly distinguished from both normal animals, which showed a narrow plate and regular and heavy calcification in the sub-epiphyseal zone, and deficient animals, with the wide epiphyseal plate almost devoid of traces of epiphyseal calcification.

\section{DISCUSSION}

In considering the results for the two series it is obvious from the $\mathrm{Ca}$ and $\mathrm{P}$ values of serum and bones that the depleted rats in the $\mathrm{C}_{4} 6$ series were more severely rachitic than those in the $\mathrm{C}_{45}$ series. The difference may have been due to the fact that the litters for $\mathrm{C}_{45}$ were autumn-born and those for $\mathrm{C}_{4} 6$ were winter-born. Fresh milk is included in the stock diet and it is probable that autumn litters would be born to does having a higher intake of vitamin $\mathrm{D}$ and passing it on to their young. There was a more marked response in bone $\mathrm{Ca}$ and $\mathrm{P}$ to a curative dose of vitamin $\mathrm{D}$ in the $\mathrm{C}_{45}$ series than in the $\mathrm{C}_{4} 6$ series. In both series the serum $\mathrm{Ca}$ and $\mathrm{P}$ values responded to vitamin $\mathrm{D}$, indicating that absorption of $\mathrm{Ca}$ and $\mathrm{P}$ was rapidly increased. However, in series $\mathrm{C}_{4} 6$, though the serum $\mathrm{Ca}$ rose to the normal level, the serum $\mathrm{P}$ failed to reach the normal level and did not approach the level achieved in $\mathrm{C}_{45}$. It would appear that the serum level of $\mathbf{P}$ in $\mathrm{C}_{4} 6$ was not adequate to permit sufficient deposition of new bone salt to show up in the ash analysis, although the histological changes indicated that calcium deposition was actively proceeding.

The leucine aminopeptidase activity of the parathyroids had significantly decreased 2 days after a dose of vitamin $\mathrm{D}$. In the $\mathrm{C}_{4} 6$ series, where comparison could be made with normal rats, the leucine aminopeptidase activity of the parathyroids after 3 days of recovery was less than in normal animals. The parathyroid activity was a reflection of the serum Ca values in that their rise in the recovery rats to normal values immediately depressed activity.

It seemed that even shorter recovery periods would be necessary in order to determine the time-activity relation between parathyroid leucine aminopeptidase activity and serum $\mathrm{Ca}$ in the vitamin D-deficient rat. It is still not clear which is the primary event.

The reason for the fall of the parathyroid leucine aminopeptidase below the normal level cannot be explained without further investigation. There would appear to be several possibilities. The parathyroids may be responding to a rapidly rising serum $\mathrm{Ca}$ even though the absolute serum $\mathrm{Ca}$ is not high. The parathyroids may have been suppressed by a high serum $\mathrm{Ca}$ at an earlier stage in the progress of recovery. On the other hand, the parathyroids may themselves be sensitive to vitamin D.

\section{REFERENCES}

Balogh, K. Jr (1962). F. Histochem. Cytochem. ro, 232.

Cheesman, E. M., Copping, A. M. \& Prebble, P. M. (1964). Br. F. Nutr. x8, 147.

Cheesman, E. M., Copping, A. M. \& Prebble, P. M. (r966). Br. F. Nutr. 20, 413.

Hume, E. M., Pickersgill, M. \& Gaffikin, M. M. (1932). Biochem. F. 26, 488.

Kramer, B. \& Shear, M. J. (1928). F. biol. Chem. 79, 147.

Lillie, R. D. (1928). Z. wiss. Mikrosk. 45, 380.

Pearse, A. G. E. (1 960). Histochemistry, 2nd ed. London: J. and A. Churchill.

Siegel, S. (1956). Nonparametric Statistics for the Behavioral Sciences. New York: McGraw-Hill. 

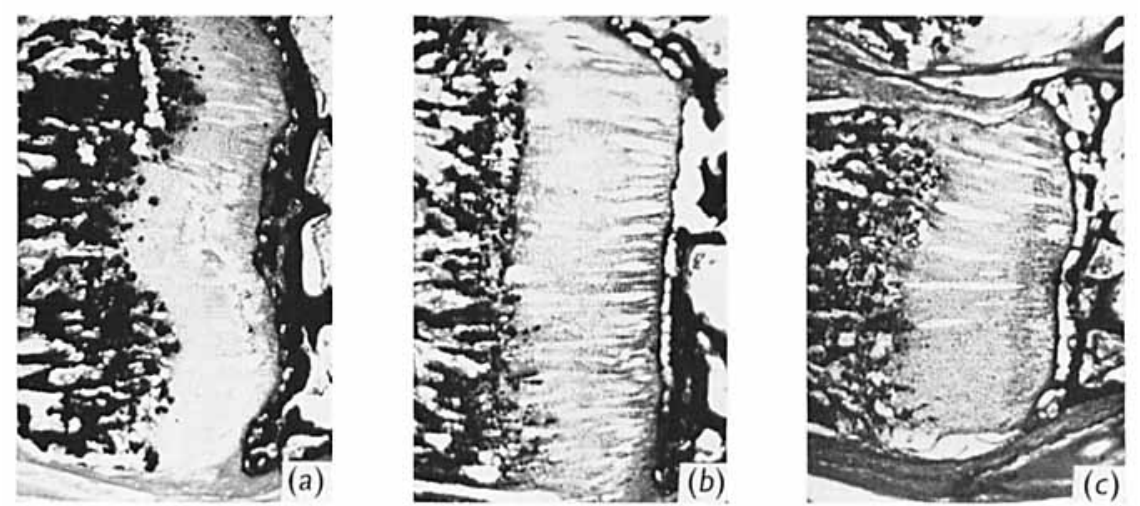

$0.65 \mathrm{~mm}$
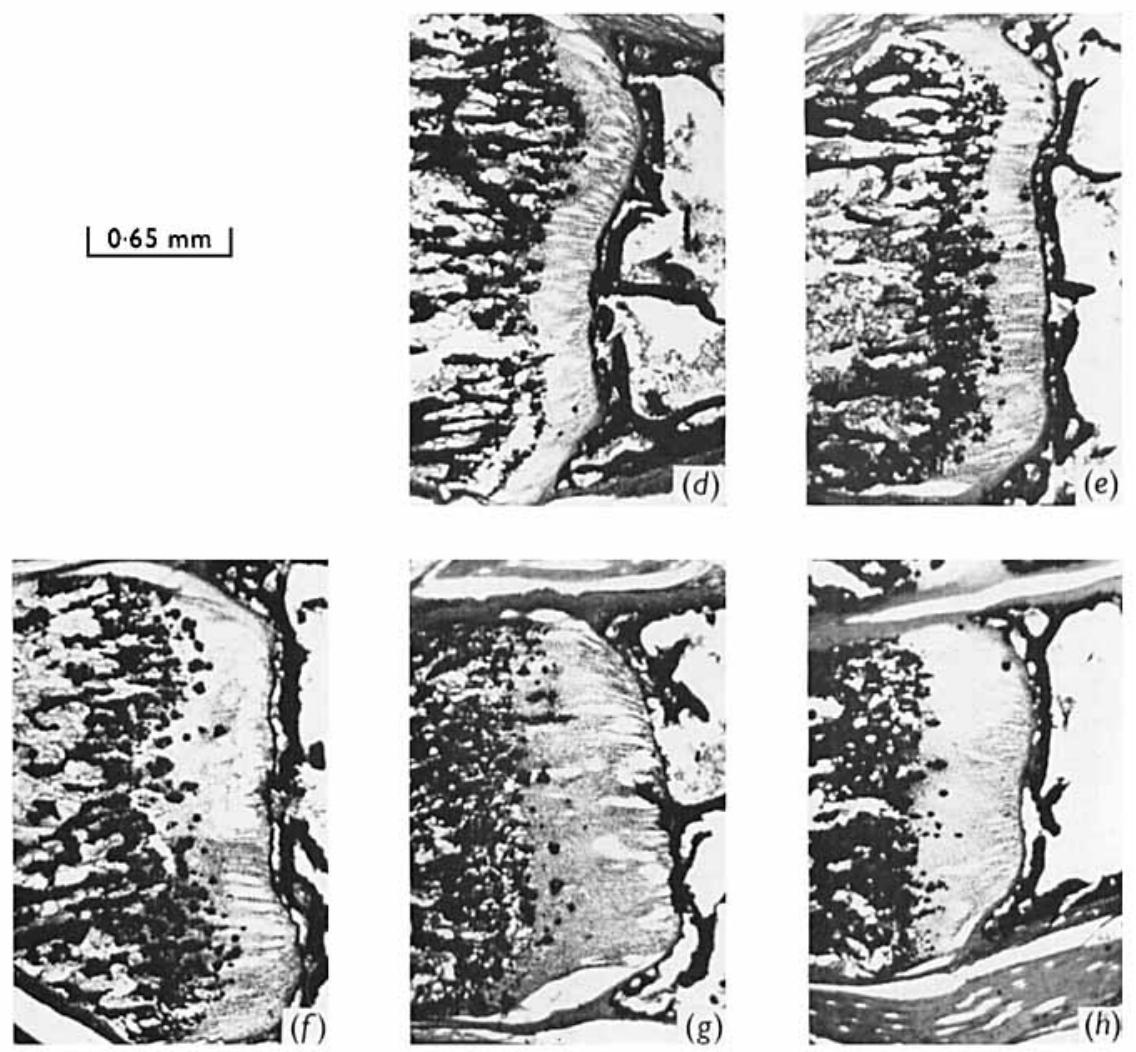
Steenbock, H. \& Black, A. (1925). F. biol. Chem. 64, 263.

Wilk, A. L. \& King, C. T. G. (1963). Nature, Lond. 198, 187.

Wilkinson, R. H. (I960). Chemical Micromethods in Clinical Medicine. Springfield, Illinois: Charles C. Thomas.

\section{EXPLANATION OF PLATE}

P1. I. Photomicrographs (prepared by Lillie's (1928) silver method) of the radius of rats given a rachitogenic diet for 28 days with either no vitamin D (deficient rats), a vitamin D supplement throughout (normal rats) or a single dose of 10 i.u. vitamin $\mathrm{D} 48 \mathrm{~h}$ or $72 \mathrm{~h}$ before being killed (recovery rats). (a) series $\mathrm{C}_{45}$ deficient rat; $(b)$ and $(c)$ series $\mathrm{C}_{46} 6$ deficient rats; $(d)$ and $(e)$ series $\mathrm{C}_{4} 6$ normal rats; $(f)$ series $\mathrm{C}_{45}$ recovery rat $48 \mathrm{~h}$ after dosing; $(g)$ and $(h)$ series $\mathrm{C}_{4} 6$ recovery rats $72 \mathrm{~h}$ after dosing. Details of series $\mathrm{C}_{45}$ and $\mathrm{C}_{46}$ are given on $\mathrm{p} .371$. 